\title{
AN ANALYSIS OF PARENT-TEACHER COMMUNICATION TOWARD THE STUDENTS' READING COMPREHENSION
}

\author{
Burhan \\ Universitas Madako, Indonesia \\ auliaburhan25@gmail.com \\ Agung Rinaldy Malik \\ Universitas Madako, Indonesia \\ agungrinaldy11@gmail.com \\ Diyenti Rusdin \\ Universitas Madako, Indonesia \\ Marzuki \\ Universitas Madako, Indonesia
}

Accepted: 2020-11-26, Approved: 2020-12-06, Published: 2020-01-18

ABSTRACT

The aims of this research are to find out that extent parents are involved in their children reading comprehension at home and to know the factors trigger the communication between parents and the English teacher toward the students reading comprehension. By using the qualitative research this study described the research finding using a triangulation technique to gather the data from the questionnaires, interview, and Focus Group Discussion (FGD) from 10 parents and one english teacher at SMA Negeri 1 Lampasio. The data analysis indicates two things. The first, parents role toward the students' reading comprehension is Low. It was found by the result of questionnaire that showed there were 10\%-20\% parents involved in their child reading comprehension at home. The second, the factors triggers the communication between parents and the English teacher were progress report that given by the English teacher to parents used an examination sheet and the same living place between parents and the English teacher.

Keywords: Parent-Teacher Communication, Reading Comprehension

\section{INTRODUCTION}

Reading is an activity to comprehend the written text. It is done by many people in the world to have knowledge. There are lots of knowledges we get after reading. That is also the reason why the students are asked to have the ability of reading comprehension.

The target of English learning in senior high school of English curriculum, School Based Curriculum (KTSP, 2006) is the students are expected to achieve informational level, because they are prepared for taking higher education. Then, the competence in reading the students are aksed to understand recount, narrative, procedural, descriptive, report, news items, analytical expostion, persuasive exposition, spoof, explanation, discussion, and review.

In asking the students to read is not an easy thing. This can be proven in SMAN 1 Lampasio after the researcher did 
a preliminary interview to the English teacher. The English teacher said that almost the students' achievement do not meet the minimum score. There were some factors that cause the problems. The first, they got difficulties to understand the meaning of almost every single word in the text, then they also got difficulties to get the main point or the topic sentence in each paragraph.

The last reason, there was a little contribution of parents at home to raise their children motivation to read. It can be proven from the result of interview to some students of SMA Negeri 1 Lampasio. They said that their parents asked them feeding their animal live stock after school and then they also have an activity at school like doing an extracurricular, while at night they have felt tired. So, they did not have time to learn English at home.

In building students skill in reading, motivation and support from their parents are needed. Parents should be involved in assisting their child to improve their schoolwork and reading comprehension. The emphasis on the family in literacy development is not an incidental one. The involvement of parents is a generally recognized factor in the success of their children. Watson (2012) said that a recent view of parent involvement research found that parentchildren reading activities produce a significant improvement in children's language and reading skill from preschool through high school.

In improving reading comprehension, the teacher also should give an information to parents about the students' achievement in reading and the difficulties they faced. Then the English teacher also can ask parents to assist their children at home. The student's reading comprehension will be improved if there is good communication and relationship of parent and teacher. Besides it is very important for parents and teachers to know the learning styles of students. (AR. Malik,
2020). (Arthun, 2014) stated that when parents participate in their children's education, both at home and at school, and experience relationship with teacher characterized by mutuality, warmth, and respect, students achieve more, demonstrate increased achievement motivation, and exhibit higher levels of emotional, social, and behavioral adjustment.

Therefore the research problems would be investigates in this research are :

1. To what extent are parents involved in their child reading comprehension at home?

2. What factors trigger the communication between parents and the English teacher?

\section{METHOD}

This research belongs to multiple case study. The researcher adopted the case study by Yin (2014). It involved determine and define the research question, select the cases, and determine data gathering and analysis technique, prepare to collect data, collect data in the field, evaluate and analyse the data, and prepare the report. This setting of the research was at SMA Negeri 1 Lampasio. The subject of the research were 10 parents of the grade eleven science major program and one the English teacher. The data were collected through in depth interview which was done to the English teacher and 10 parents, then Questionnaire was given to 10 parents, and Focus Group Discussion was done to 7 parents because 3 parents did not attend the group discussion.

\section{RESULT AND DISCUSSION}

\section{The Result of Reading Examination}

The result of the students at SMA Negeri 1 Lampasio showed that almost of 
them still difficult in understanding the written text. The researcher took 10 students' reading score from the English teacher, then it could be seen in table below: Table 1. The Score of Reading

\begin{tabular}{|c|c|c|}
\hline No. & Name & Score \\
\hline 1. & AS & 30 \\
\hline 2. & DAA & 75 \\
\hline 3. & IGNS & 60 \\
\hline 4. & IKS & 85 \\
\hline 5. & MPS & 70 \\
\hline 6. & NW & 70 \\
\hline 7. & NES & 05 \\
\hline 8. & NSM & 50 \\
\hline 9. & RA & 70 \\
\hline 10. & VA & 55 \\
\hline
\end{tabular}

From the table above, it can be seen that there were 5 out of 10 students got successful score, while the others or there 5 out of 10 students got unsuccessfu score. Then, the highest score was 85 and the lowest score was 05 . It can be concluded that almost of the students comprehension in reading was Low. The score also supported by the English teacher statement in the interview. She said that almost of the students' score do not meet the minimum standard score.

\section{The Result of the Relationship of the Students' Score with Parents' Level Education}

The result of the students' score with parents' level education was gotten by the data of parents given by the staff in SMA Negeri 1 Lampasio and the result of the students score were given by the English teacher. After analyzing the data, the researcher then concluded that there was not any relationship with the students successful or unsuccessful score with the level of parents education. To make it more clear, the researcher put it in a diagram

below

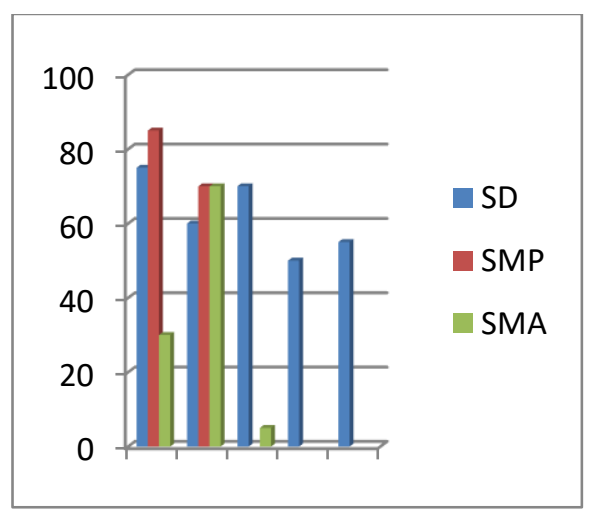

Figure 1. The Level of Parents' Education 
By the diagram abve, it can be seen that there was not any relationship between parents level education and the students education score. The first thing that can be seen was the highest score which was gotten by the student whose parent graduated from junior high school and the second was the student who got the lowest score was the student whose parent graduated from senior high school.

\section{Parents Perspective about the Importance of Reading}

The information about the parents perspective about the importance of reading was gotten by the in depth individual interview which was done on July, 23rd 2017. In this activity, the researcher asked parents about their opinion of the importance of reading. Then, almost of parents said that reading is important because by having a good skill in reading, their child can get knowledge. It means that all parents agreed that reading is importance.
Basicly almost all parents agree that reading is important, but there were some of them seemed did not understand about it, they knew that everything that students learn at school is an important thing. They did not understand about it caused of the level of their education. Many parents of the students at SMA Negeri 1 Lampasio o were graduated from elementary school, Junior high school, and senior high school, while the others never go to school

\section{The Role of Parents in Assisting Reading at Home}

In this research, the researcher found out the role of 10 parents in assisting their child at home by using questionnaire. By the result of the questionnaire, the researcher then concluded that the role of parents in assiting their child at home was Low. To make it clear, it can be seen in the diagram below.

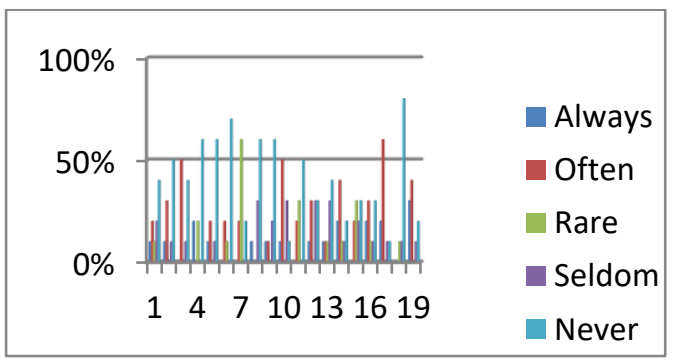

Figure 2. Parents' Role of in assisting their children

By the diagram above, it can be seen that parents choice never in almost number of activity in the questioner and the column never also become the highest chioce. While there were only 3 activities that parents chose often, and the lowest choice was the column usually. In the diagram showed that only $10 \%-20 \%$ parents usually assist their child at home, while the other did it rarely until never did it. 


\section{The Communication between parent and the English Teacher}

The information about the communication between parent and the English teacher was gotten by Focus Group Discussion (FGD). It was done on July, 22nd 2017. There were 7 parents attended this meeting. By the meeting, the researcher then know that some parents build the communication by meeting the teacher in the market or in her house. Parents who met the English teacher in her house usually was parents who have made an appointment, then the other who met her outside were parents who met her without any planning.

The first question given by the researcher in FGD was parents perspective about having relationship with the English teacher. Then by the answer given from the ten parents, the researcher concluded that they all agree that having relationship with the English teacher is good, but they did not know what should they say and some of them felt shy. They did not know how to start the relationship and in what condition they should meet the English teacher.

The second question was about the information the English teacher give about their child at school. The answer of the question was the English teacher always report the result of the examination test to parents. In this time, parents should sign on the paper, then after it was signed it should be given back to the English teacher.

The third topic in FGD was about the communication that the parents build with the English teacher. From this discussion, the researcher then concluded that there was not any parent who met the English teacher at the school. Some of them met the English teacher outside, in the English teacher house, in the market, or in the

shop, while the others said that they never met the English teacher.

The topic that was discussed by parents to the English teacher were about the attitude, the improvement, and the weaknesses of their child in the process of learning English in the classroom. By the discussion, usually the English teacher would ask them to support their child in learning English by preparing a dictionary and time to learn English with their friends because the students who are active in learning with their friends have shown a good result.

The result of the discussion between parents and the English teacher showed that parents buy the dictionary, control their child to learn at home, then motivate them to learn English at home. However some of their child can not do that because they have thought that English is difficult and they have to help their parents after school, and at night they go out to hang out with their friends. So, almost their time at home not for learning.

So, the researcher concluded that the communication between parents and the English teacher were about the attitude, the weaknesses, and the improvement of students in the process of teaching and learning.

\section{The Communication between the English Teacher and Parent}

In this research, the researcher did an interview with the English teacher at SMA Negeri 1 Lampasio. There were some questions given to the English teacher about the way the teacher communicate to the parents. The first question was about the teacher perspective about the relationship of teacher with parents. Then, the answer was very important. The English teacher said that it is very important because it can make parents 
understnd about their child ability in English and what parents should do to help their child in reading skill.

After the question answered well, the researcher then continue the question by asking the English teacher to describe her relationship with parents. The English teacher explained that there were two kinds of relationship she did. They were direct and indirect relationship. In direct relationship, she met parents whose child score was very low. She informed about the score and the attitude of the child at school. While in indirect relationship, she asked parents to sign the examination sheet that has score of the students. From the sheet, the teacher hopes that parents can see their child score.

After that, the researcher also checked about the expression of parents after having the information about their child bad or failure score. The teacher said that the parents who have good communication with her will ask about it and asking what they should do at home. While the others although they live in the same village, they seemed did not care about it. She added that it caused of they did not understand about it.

The result of the interview showed the thing that the English teacher do is to have communication or relationship to parents is asking parents to sign in the examination sheet that has a score of the students on it.
It also then can be concluded that the English teacher used a progress report. Then by the sheet, some parents looked give effort to meet her, but almost parents seemed do not care caused they do not understand and the place they live is far. Then the last, the teacher also hope parents wanted to meet her at school formally because she can not meet them one by one.

\section{The Role of Parents whose Child Got Successful and Unsuccessful Score in Building their Communication to the English Teacher}

To get the data about the role of parents whose child got successful and unsuccessful score, the researcher then relate the result of interview and the students' score. In this activity, the researcher differ the students based on their successful ans unsuccessful score. So it became two groups.

In the first group about the students who got successful score, the researcher found that almost parents in this group have a relationship with the English teacher. It also proved that having good communication with the English teacher give good impact to the students' score. In this research, there were 5 out of 10 students who get successful score. To make it clear, the researcher put it in table below

Table 2. The Successful Students

\begin{tabular}{|c|c|}
\hline Name & Score \\
\hline DAA & 75 \\
\hline IKS & 85 \\
\hline MPS & 70 \\
\hline NW & 70 \\
\hline RA & 70 \\
\hline
\end{tabular}


By the diagram above, then it can be seen that the highest score was 85 and the others were 70 and 75 . After that the researcher interviewed the five mothers to know about their role toward their child reading comprehension at home.

The result of the interview of 5 parents about their communication to the English teacher was almost of them have good communication to the English teacher. They asked the English teacher whenever they were or wherever they met the English teacher. They asked the English teacher about their child attitude, improvement, and weaknesses. Although, there was 1 of the parents never met the English teacher, but she said she always support her child in reading English book.

By the result of the communication between parents and the English teacher showed that there was an important contribution of parents communication and the English teacher toward the students' reading comprehension. Fan and Chen (2001) stated that generally, when parents participate in their children's education, both at home and at school, and experience relationship with teachers characterized by mutuality, warmth, and respect, students achieve more, it will show a better achievement motivation.

In the second group about the students who got unsuccessful score, the researcher found out that almost parents whose child got unsuccessful score never meet the English teacher. By this finding, it also can be concluded that the communication between parents and the English teacher infuenced the students' score. The students' reading unsuccesful score can be seen in table below :

Table 3. The Unsuccessful Students

\begin{tabular}{|c|c|}
\hline Name & Score \\
\hline AS & 30 \\
\hline IGNS & 60 \\
\hline NES & 05 \\
\hline NSM & 50 \\
\hline VA & 55 \\
\hline
\end{tabular}

Table above showed that the lowest score was 05 , then it followed by the higher score 30, 50,55, and 60 although they were notsuccessful score. By the score, the researcher then analyzed their parents role in building communication with the English teacher.

The result of the interview showed that almost of parents whose child got unsuccessful score. They said they felt shy and did not know that they could talk about their child score with the English teacher. While there was 1 parent who always met the English teacher, she also given some information about her child and got advice from the English teacher. However, she could not push her child to learn at home because her child was busy almost of the day. She said that her child should help his father to feed their animal live stock after school and at night he was tired to read or do his homework.

By the result of the interview the researcher also concluded that parents whose child got unsuccessful score did not know what should they asked to their child to do at home.Then, basicly they really like tohave a good communication, but 
they felt shy and they live in different village with the English teacher.

\section{Factors Trigger the Communication between parents and the English teacher}

In this research, the researcher find out the communication trigger the communication between parents and the English teacher by concluding the interview to parents. There were two factors that influenced parents to have communication with the English teacher. The first was about the progrees report. The progress report was about the examiation sheet which has the students score on it. The examination sheet should be signed by parents. Then, by signing the sheet parents know about their child score. Some parents who care of their child would meet the English teacher to ask about it. However, there were many parents did not do it because they were shy and did not know about things that they should discuss to the English teacher.

The second factor was the same living place. This factor can give parents who feel shy to come to the English teacher to ask about their child improvement or weaknesses in the process of teaching and learning. And, by this factor the English teacher also can communicate about the students weaknesses or attitude to parents.

\section{DISCUSSION}

Based on the result of the research finding above, it can be seen that almost parents need an advice or information about things they should do at home and they need to discuss about their understanding about their child's ability in reading skill. They believe that if they have the information about things they should do at home, they may assist their child well at home. Kharrat (2018) stated that communication needs to be clear, consistent, and positive, and parents need to believe that they play an important role in their children's learning.

Based on the result of the questionnaire, the researcher then concluded that from nineteen activities, there were fifteen activities that has been really done by many parents. Clark (2011) stated that research indicates that three strategies or types parental involvement that exist: (1) home-based involvement (2) school-based involvement (3) academic socialization. Then Hartlep and Ellis (2010) also continued that home-based involvement involves the parents helping with homework and taking children to educational settings and such as nuseun and libraries. However, from the activities they chose there were many misunderstanding, so the main activity that all parents really do was asking their child to learn at home. That is also become one of the conclusions why the researcher conlude that the role of parents in assisting their child at home was Low. Then, the second reason was there were only 1 $(10 \%)$ to $2(20 \%)$ out of 10 parents chose usually to assist their child at home, while the highest was they never assits their child reading comprehension at home.

The communication between parents and the English teacher based on the result of the interview were about the attitude, the improvement, and the weaknesses of their child in the process of learning English. While in the end of the communication, the English teacher would advice the parents about the things that their child need in the process of learning English. One of the things that should be prepared by parents was dictionary.

From the communication between parents and the English teacher, the researcher then analyzed factors trigger the communication. The researcher found tht there were two factors caused the 
communication, They were the progress report given by the English teacher every after giving score to the students. By this activity, parents were asked to sign on the examination score. By the activity, the teacher hopes parents would get infomation about the improvement or weaknesses of their child in learning English, especially in reading skill. In Journal Extension (2014) is written that Parent Progress Report is a tool to provide families with semi-annual feedback in the areas of communication, youth attendance, submitting copies of youth report cards, parents volunteerism, and attendance at family program.

Then the last factor was the same living place. Parents who live in the same village with the English teacher, get easier to meet the English teacher. Also their relationship can be good because they can meet outside, in the shop or market, or come to the English teacher' house. It means they can meet the English teacher by making appointment before and without any appointment.

Parents who did not have communication with the English teacher does not mean they did not care with their child. From this research there were two factors caused they did not have any relationship with the English teacher. The first was they did not have any knowledge that they can discuss about their child score with the English teacher and the second was they live in difference village with the English teacher. Boonk (2018) said that there are multiple reasons of non involvement parents, they are they may not know that they are expected to be involved in their children's education, some cultures believe that the teacher ia a higher authority figure and the parents may not want to intefere with the teacher's authority, some parents may work several works and simply not have the time to be involved, and the last was some families may not have transportation or the ability for childcare in order to visit the school.

The communication between parents and the English teacher also give impact for the students' score. The researcher found that the almost students whose parents build a good relationship with the English teacher got successful score. This finding also line with Olcer and Kocer (2015) who said that teacher and parent relation bear an increasing importance school as learning communities and for students' growth through meeting their needs and expectations.

\section{CONCLUSION}

The result of analyzing parentteacher communication toward the students' reading comprehension are parents' role toward the students' reading comprehension is Low because the the activity of parents in assisting their child reading at home only $10 \%$ to $20 \%$. Then, factors trigger thecommunication are progress report which given to parents in every examination has been scored by the English teacher and the same living place of parents and the English teacher.

\section{ACKNOWLEDGEMENT}

The researchers would like to express gratitude to all elements who contribute significantly to make this project is conducted successfully.

\section{REFFERENCES}

Aarthun, A., \& Akerjordet, K. (2014). Parent participation in decisionmaking in health-care services for children: an integrative 
review. Journal of Nursing Management, 22(2), 177-191.

Boonk, L., Gijselaers, H. J., Ritzen, H., \& Brand-Gruwel, S. (2018). A review of the relationship between parental involvement indicators and academic achievement. Educational Research Review, 24, 10-30.

Clark, L. S. (2011). Parental mediation theory for the digital age. Communication theory, 21(4), 323-343.

Fan X, Chen M. 2011. Parental involvement and students, academic achievement: A metaanalysis. Educational Psychology Review. 13:1-22.

Hartlep, N. D., \& Ellis, A. (2010). Are household income, gender, and race important in shaping parental involvement in children's education? Online Submission. Retrieved from http://ezproxy.lib.ucf.edu/login?UR L=http://search.ebscohost.com/logi n.aspx?direct $=$ true $\& \mathrm{db}=$ eric $\& A N=$ ED512394\&site $=$ ehost-live

Kharrat, A., Moore, G. P., Beckett, S., Nicholls, S. G., Sampson, M., \& Daboval, T. (2018). Antenatal consultations at extreme prematurity: a systematic review of parent communication needs. The Journal of pediatrics, 196, 109-115.

Journal Extension. (2014). Increasing Parent Involvement with Parent
Progress Report. Ohio State University Extension: Dayton Ohio. April 2014 // Volume 52 // Number 2 // Tools of the Trade // 2 TOT9.

https://joe.org/joe/2014april/tt9.ph p. Downloaded on $2 / 02 / 18$.

Malik, A. R., Emzir, E., \& Sumarni, S. (2020). Pengaruh Strategi Pembelajaran Mobile Learning dan Gaya Belajar Visual Terhadap Penguasaan Kosakata Bahasa Jerman Siswa Sma Negeri 1 Maros. Visipena, 11(1), 194-207.

Departemen Pendidikan Nasional (Depdiknas). (2006). Kurikulum Tingkat Satuan Pendidikan (KTSP). Jakarta : Depdiknas.

Olcer, N. \& Kocer, S. (2015). Organizational Communication : A survey on the academic staff at Kocaeli University. Global Media Journal TR Edition, 6 (11), 339383.

Watson, G. L., Sanders-Lawson, E. R., \& McNeal, L. (2012). Understanding parental involvement in American public education. International Journal of Humanities and Social Science, 2(19), 41-50.

Yin. 2014. Case Study Research Design and Methods (5th Ed.). Thousand Oaks, CA : Sage . (ISBN 978-14522-4256-9). 